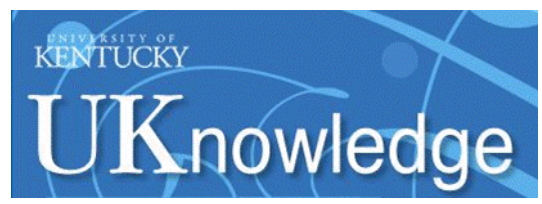

University of Kentucky

UKnowledge

9-9-2015

\title{
Differential Expression of mRNA Encoding Cytokines and Chemokines in the Reproductive Tract after Infection of Mice with Chlamydia trachomatis
}

\author{
Katheryn L. Cerny \\ University of Kentucky, katheryn.cerny@gmail.com \\ Maranda Van Fleet \\ University of Kentucky, maranda.vanfleet@uky.edu \\ Anatoly Slepenkin \\ University of California - Irvine \\ Ellena M. Peterson \\ University of California - Irvine \\ Phillip J. Bridges \\ University of Kentucky, phillip.bridges@uky.edu \\ Follow this and additional works at: https://uknowledge.uky.edu/animalsci_facpub \\ Part of the Animal Sciences Commons, Food Science Commons, and the Reproductive and Urinary \\ Physiology Commons \\ Right click to open a feedback form in a new tab to let us know how this document benefits you.
}

\section{Repository Citation}

Cerny, Katheryn L.; Van Fleet, Maranda; Slepenkin, Anatoly; Peterson, Ellena M.; and Bridges, Phillip J., "Differential Expression of mRNA Encoding Cytokines and Chemokines in the Reproductive Tract after Infection of Mice with Chlamydia trachomatis" (2015). Animal and Food Sciences Faculty Publications. 9. https://uknowledge.uky.edu/animalsci_facpub/9

This Article is brought to you for free and open access by the Animal and Food Sciences at UKnowledge. It has been accepted for inclusion in Animal and Food Sciences Faculty Publications by an authorized administrator of UKnowledge. For more information, please contact UKnowledge@lsv.uky.edu. 


\title{
Differential Expression of mRNA Encoding Cytokines and Chemokines in the Reproductive Tract after Infection of Mice with Chlamydia trachomatis
}

\author{
Digital Object Identifier (DOI) \\ https://doi.org/10.4172/2161-038X.1000152 \\ Notes/Citation Information \\ Published in Reproductive System \& Sexual Disorders: Current Research, v. 4, issue 3, 1000152, p. 1-8. \\ (C) 2015 Cerny KL, et al.
}

This is an open-access article distributed under the terms of the Creative Commons Attribution License, which permits unrestricted use, distribution, and reproduction in any medium, provided the original author and source are credited. 


\title{
Reproductive System \& Sexual Disorders: Current Research
}

\section{Differential Expression of mRNA Encoding Cytokines and Chemokines in the Reproductive Tract after Infection of Mice with Chlamydia trachomatis}

\author{
Katheryn L. Cerny ${ }^{1}$, Maranda Van Fleet ${ }^{1}$, Anatoly Slepenkin ${ }^{2}$, Ellena M. Peterson ${ }^{2}$ and Phillip J. Bridges ${ }^{1^{*}}$ \\ ${ }^{1}$ Department of Animal and Food Sciences, University of Kentucky, Lexington, KY, USA \\ ${ }^{2}$ Department of Pathology and Laboratory Medicine, University of California Irvine, Irvine, CA, USA
}

"Corresponding author: Bridges PJ, Ph.D, Department of Animal and Food Sciences, University of Kentucky, Lexington KY, USA, Tel: 8592574877 ; Fax: 859257 5318; E-mail: phillip.bridges@uky.edu

Rec date: Aug 06, 2015; Acc date: Sep 02, 2015; Pub date: Sep 09, 2015

Copyright: ( 2015 Cerny KL, et al. This is an open-access article distributed under the terms of the Creative Commons Attribution License, which permits unrestricted use, distribution, and reproduction in any medium, provided the original author and source are credited.

\begin{abstract}
Infection with Chlamydia trachomatis targets epithelial cells within the genital tract which respond by secreting chemokines and cytokines. Persistent inflammation can lead to fibrosis, tubal infertility and/or ectopic pregnancy; many infections are asymptomatic. Most studies have investigated the inflammatory response in the initial stages of infection, less is known about the later stages of infection, especially with a low, potentially asymptomatic, bacterial load. Our objective was to determine the inflammatory mediators involved in clearance of low-grade infection and the potential involvement in chronic inflammation. Six to eight week old $\mathrm{C} 3 \mathrm{H} / \mathrm{HeJ}$ mice were pretreated with $2.5 \mathrm{mg}$ medroxyprogesterone acetate on day -10 and -3 before infection. Mice ( $n=3$ for $28 d, n=3$ for $35 d$ ) were infected with $5 \times 10^{2}$ inclusion-forming units of $C$. trachomatis, serovar $D$; vaginal cultures were obtained weekly to monitor infection. Control mice ( $\mathrm{n}=3$ for $28 \mathrm{~d}, \mathrm{n}=3$ for $35 \mathrm{~d}$ ) were sham infected. Mice were killed on day 28 (experiment 1 ) and day 35 (experiment 2) post-infection and vaginal tissue, uterine horns and oviducts collected for analysis of mRNAs encoding inflammatory cytokines and chemokines. Total RNA was isolated and a superarray analysis performed using mouse Cytokines and Chemokines PCR arrays (Qiagen, Valencia, CA). Statistical differences in gene expression were determined using a paired Students t-test. At 28 days after infection, the expression of mRNA encoding 6, 35 and 3 inflammatory genes differed from controls in vaginal, uterine and oviductal tissues, respectively $(P<0.05)$. At 35 days after infection, the expression of mRNA encoding 16, 38 and 14 inflammatory genes differed from controls in vaginal, uterine and oviductal tissues, respectively $(P<0.05)$. Understanding the mechanisms involved in the inflammatory response at later stages of infection should aid in the development of treatment options that minimize the development of asymptomatic, chronic inflammation-induced infertility.
\end{abstract}

Keywords: Chlamydia trachomatis, Oviduct; Inflammation; Cytokines; Chemokines; Immune response

\section{Introduction}

Chlamydia trachomatis is an obligate intracellular pathogen and the most frequently reported sexually transmitted bacteria in the United States [1]. C. trachomatis targets epithelial cells within the genital tract initiating an immune response. Infectious load is correlated to clinical pathogenesis [2,3]; infection with $C$. trachomatis is often asymptomatic. If left untreated the bacteria can ascend to and infect the oviducts $[4,5]$. Untreated $C$. trachomatis infection can lead to persistent or recurrent inflammation, fibrosis, scarring, pelvic inflammatory disease (PID), tubal infertility, and/or an increased susceptibility to ectopic pregnancy [6,7].

Upon infection, C. trachomatis elementary bodies (EBs) invade host epithelial cells in the genital tract. Within the host cells, EBs differentiate into reticulate bodies (RBs) which actively replicate within the host cell cytoplasm and then reorganize back into infectious EBs. This biphasic life cycle as well as adaptation to evade the immune response allows $C$. trachomatis to persist for extended periods within host epithelial cells, inducing a chronic inflammatory response [8-12].

Previous studies have investigated the inflammatory response of $C$. trachomatis in the initial stages of infection, including regulation by cytokines, chemokines and inflammatory mediators involved in the recruitment of immune cells $[5,8,10,13,14]$. For example, Rasmussen et al. [10] demonstrated that once $C$. trachomatis has established infection within epithelial cells, the innate immune response allows for the production of pro-inflammatory cytokines such as interleukins 1 , 6, 8 (Il-1, Il-6, Il-8), tumor necrosis factor-alpha (TNF- $\alpha$ ), and colony stimulating factor 2 (CSF 2). Secretion of these cytokines and chemokines recruit immune cells such as natural killer (NK) cells and phagocytes. Following an established intracellular infection, the T-cell mediated immune response then becomes the critical element required for clearance [15]. However, evidence suggests that this T-cell response also contributes to the pathology following infection. Th1 cells limit replication of $C$. trachomatis, but Th2 cells inhibit Th1 responses leading to continued production of pro-inflammatory cytokines which can lead to fibrosis [16]. C. trachomatis also induces production of TNF- $\alpha$, which promotes apoptosis of infected and bystander cells [17]. Overall, understanding cytokine and chemokine regulation during both acute and chronic phases of infection may contribute to the development of treatment options that will minimize the long-term inflammatory consequences attributed to this disease.

Limited investigation of the overall inflammatory response during the later stages of infection has been performed, especially after infection with a low bacterial load. For example, Maxion and Kelly [5] used $10^{7}$ IFUs of the mouse pneumonitis biovar of $C$. trachomatis and reported that cytokine and chemokine expression differs in anatomically distinct regions of the genital tract. Specifically, these authors investigated the expression of chemokines associated with Th1 
Citation: Cerny KL, Fleet MV, Slepenkin A, Peterson EM, Bridges PJ (2015) Differential Expression of mRNA Encoding Cytokines and Chemokines in the Reproductive Tract after Infection of Mice with Chlamydia trachomatis . Reprod Syst Sex Disord 4: 1000152. doi:

Page 2 of 8

and Th2 responses in the oviducts and cervical-vaginal regions of the reproductive tract during the induction phase (0-14 days) and resolution phase (14-35 days) of infection. Our objective was to determine within the reproductive tract the concurrent level of expression of mRNA encoding inflammatory mediators during the later phases of infection using a relatively low infectious load of $C$. trachomatis biovar, serovar $\mathrm{D}$, one of the most prevalent serovars involved in urogenital infections of humans [18]. Two separate experiments were performed, with tissues collected at 4 and 5 weeks after infection (experiment 1 and 2, respectively). Our hypothesis was that mRNA encoding pro-inflammatory cytokines and chemokines will be differentially expressed in the female reproductive tract of mice infected with $C$. trachomatis at both 28 and 35 days post-infection compared to controls.

\section{Materials and Methods}

\section{Ethics statement}

All animal experiments were performed according to the guidelines and protocol approved by the University of California Irvine Institutional Animal Care and Use Committee (protocol \# 2009-2868).

\section{Animal model}

Using a previously described model of confirmed genital infection by $C$. trachomatis, serovar $\mathrm{D}$, female $\mathrm{C} 3 \mathrm{H} / \mathrm{HeJ}$ mice, 6 - to 8 -week old, (Jackson Laboratories, Sacramento, CA) were pretreated with $2.5 \mathrm{mg}$ medroxyprogesterone acetate (SICOR Pharmaceuticals) on Days -10 and -3 before infection $[19,20]$. In both experiments mice were infected via vaginal challenge with $5 \times 10^{2}$ inclusion-forming units (IFUs) of C. trachomatis, serovar D in $0.01 \mathrm{~mL}$ of Eagle Minimal essential media (MEM, Gibco) on Day 0, as previously described $[19,20]$. Control mice were also pretreated with medroxyprogesterone acetate, but were sham infected with Eagle Minimal essential media (MEM, Gibco) alone. Vaginal swabs were obtained twice weekly after infection and cell cultures were performed to monitor infection as previously described [19-21].

Mice were killed on day 28 ( $\mathrm{n}=3$ for control and infected) in experiment 1 and day 35 ( $\mathrm{n}=3$ for control and infected) in experiment
2. Immediately before being sacrificed vaginal cultures were obtained and all mice inoculated vaginally with $C$. trachomatis remained culture positive but at a significantly lower level than that obtained throughout the first two weeks of infection. Results of vaginal cultures following infection with this strain/dose of $C$. trachomatis, serovar D have been reported, including number of IFUs recovered [20]. Vaginal tissue, uterine horns and the oviducts were collected and snap-frozen for later extraction of RNA.

\section{Isolation of RNA and gene expression analysis}

Total RNA was extracted from each tissue sample using TRIzol reagent (Invitrogen, Carlsbad, CA) and purified through RNeasy columns (Qiagen, Valencia, CA). To determine the effect of treatment on the expression of genes involved in the inflammatory response, a targeted real time PCR SuperArray analysis was performed using RT2 Profiler PCR arrays for mouse Cytokines and Chemokines (Qiagen), as previously described [22]. Real-time PCR were performed on an Eppendorf Mastercycler ep realplex2 system (Eppendorf, Hamburg, Germany).

Gene expression was standardized against GAPDH as a housekeeping gene and analyzed by the $2-\Delta \Delta \mathrm{CT}$ method [23]. Statistical differences in the expression of mRNA were determined using a paired Students t-test.

\section{Results}

\section{Experiment 1: Expression of mRNA encoding inflammatory genes in vaginal, uterine and oviduct tissues at 28 days post- infection}

Gene expression analysis was used to determine the effect of infection on the expression of inflammatory mRNAs at 28 days postinfection. In vaginal tissue collected at 28 days after infection, the expression of mRNA encoding 6 inflammatory genes increased and no genes decreased when compared to controls (Table 1).

\begin{tabular}{|c|c|c|c|c|}
\hline \multicolumn{5}{|c|}{28 Day infected vs. control } \\
\hline Gene Symbol & $\begin{array}{l}\text { Control Avg. } \Delta \mathrm{C}+ \\
\text { SEM }\end{array}$ & $\begin{array}{l}\text { Infected Avg. } \\
\Delta C+\text { SEM }\end{array}$ & Fold change & p-value \\
\hline $\mathrm{Ccl} 24$ & $12.79 \pm 0.76$ & $10.62 \pm 0.53$ & 4.5 & 0.007 \\
\hline $\mathrm{Ccl} 3$ & $10.18 \pm 0.54$ & $7.81 \pm 1.00$ & 5.5 & 0.025 \\
\hline $\mathrm{Ccl} 4$ & $9.03 \pm 0.59$ & $6.28 \pm 0.44$ & 6.7 & 0.036 \\
\hline Cd40lg & $14.01 \pm 0.30$ & $11.05 \pm 0.36$ & 7.8 & 0.011 \\
\hline Cxcl1 & $9.00 \pm 0.25$ & $6.18 \pm 0.24$ & 7.1 & 0.028 \\
\hline II22 & $15.96 \pm 0.37$ & $15.03 \pm 0.39$ & 1.9 & 0.024 \\
\hline \multicolumn{5}{|c|}{35 day infected vs. control } \\
\hline Bmp7 & $6.43 \pm 0.17$ & $6.51 \pm 0.25$ & 0.5 & 0.032 \\
\hline
\end{tabular}


Citation: Cerny KL, Fleet MV, Slepenkin A, Peterson EM, Bridges PJ (2015) Differential Expression of mRNA Encoding Cytokines and Chemokines in the Reproductive Tract after Infection of Mice with Chlamydia trachomatis . Reprod Syst Sex Disord 4: 1000152. doi: 10.4172/2161-038X.1000152

Page 3 of 8

\begin{tabular}{|l|l|l|l|l|}
\hline Csf3 & $4.88 \pm 0.05$ & $5.47 \pm 0.06$ & 0.5 & $<0.001$ \\
\hline Cc14 & $9.03 \pm 0.58$ & $6.28 \pm 0.23$ & 4.2 & 0.019 \\
\hline Ctf1 & $6.67 \pm 0.15$ & $7.19 \pm 0.12$ & 0.6 & 0.023 \\
\hline Hprt & $1.65 \pm 0.14$ & $1.81 \pm 0.04$ & 0.6 & 0.022 \\
\hline Ifna2 & $11.3 \pm 0.19$ & $11.41 \pm 0.24$ & 0.4 & 0.014 \\
\hline Ifng & $13.04 \pm 0.54$ & $9.68 \pm 0.43$ & 8.5 & 0.035 \\
\hline II10 & $9.94 \pm 0.38$ & $8.35 \pm 0.32$ & 2.8 & 0.048 \\
\hline II11 & $11.76 \pm 0.07$ & $10.52 \pm 0.23$ & 2.3 & 0.03 \\
\hline II18 & $5.86 \pm 0.22$ & $6.54 \pm 0.06$ & 0.4 & 0.014 \\
\hline II1a & $7.13 \pm 0.09$ & $5.97 \pm 0.04$ & 1.4 & 0.007 \\
\hline II1rn & $6.36 \pm 0.37$ & $5.95 \pm 0.13$ & 1.9 & 0.042 \\
\hline Mif & $0.43 \pm 0.12$ & $0.76 \pm 0.08$ & 0.7 & 0.045 \\
\hline Pf4 & $5.15 \pm 0.19$ & $5.26 \pm 0.06$ & 0.6 & 0.031 \\
\hline Thpo & $12.95 \pm 0.6$ & $13.76 \pm 0.16$ & 3.7 & 0.019 \\
\hline Tnf & $8.4 \pm 0.19$ & $6.86 \pm 0.09$ & 2.4 & 0.002 \\
\hline
\end{tabular}

Table 1: Effect of treatment on the expression of mRNAs in the vagina at 28 and 35 days post-infection. The normalized average $\Delta \mathrm{C}+$ value was calculated using GAPDH as the house-keeping gene. Fold change values (infected over control) in gene expression are presented as average fold change $\left(2^{-(\text {average } \mathrm{Ct})}\right)$ for differentially expressed mRNAs $(\mathrm{P}<0.05)$.

In uterine samples collected at 28 days after infection, the expression of mRNA encoding 32 inflammatory genes increased and 3 genes decreased when compared to controls (Table 2).

\begin{tabular}{|c|c|c|c|c|c|c|c|c|c|}
\hline \multicolumn{10}{|c|}{28 Day infected vs. control } \\
\hline $\begin{array}{l}\text { Gene } \\
\text { Symbol }\end{array}$ & $\begin{array}{l}\text { Control Avg. } \Delta \mathrm{C} \\
+ \text { SEM }\end{array}$ & $\begin{array}{l}\text { Infected Avg. } \Delta \mathrm{C}+ \\
\text { SEM }\end{array}$ & $\begin{array}{l}\text { Fold } \\
\text { Change }\end{array}$ & p-value & Gene Symbol & $\begin{array}{l}\text { Control Avg. } \Delta \mathrm{C}+ \\
\text { SEM }\end{array}$ & $\begin{array}{l}\text { Infected Avg. } \Delta \mathbf{C}+ \\
\text { SEM }\end{array}$ & $\begin{array}{l}\text { Fold } \\
\text { Change }\end{array}$ & p-value \\
\hline Ccl1 & $13.84 \pm 0.32$ & $12.03 \pm 0.32$ & 3.5 & 0.04 & ॥16 & $7.41 \pm 0.17$ & $6.24 \pm 0.27$ & 2.2 & 0.045 \\
\hline $\mathrm{Ccl} 17$ & $9.56 \pm 0.11$ & $7.76 \pm 0.21$ & 3.5 & 0.009 & II27 & $11.83 \pm 0.11$ & $9.70 \pm 0.15$ & 4.4 & 0.002 \\
\hline Ccl2 & $7.31 \pm 0.29$ & $4.53 \pm 0.35$ & 6.8 & 0.025 & Lta & $11.01 \pm 0.21$ & $9.01 \pm 0.37$ & 4 & 0.037 \\
\hline $\mathrm{Ccl} 22$ & $9.18 \pm 0.13$ & $7.45 \pm 0.31$ & 3.3 & 0.025 & Ltb & $6.85 \pm 0.16$ & $3.58 \pm 0.29$ & 9.6 & 0.009 \\
\hline $\mathrm{Ccl} 24$ & $11.64 \pm 0.13$ & $12.81 \pm 0.30$ & 0.4 & 0.018 & Tgfb2 & $0.67 \pm 0.04$ & $2.57 \pm 0.76$ & 0.3 & 0.03 \\
\hline $\mathrm{Ccl} 3$ & $11.52 \pm 0.34$ & $8.49 \pm 0.13$ & 8.2 & 0.001 & Tnf & $9.77 \pm 0.22$ & $6.93 \pm 0.30$ & 7.2 & 0.013 \\
\hline $\mathrm{Ccl} 4$ & $9.73 \pm 0.39$ & $6.41 \pm 0.15$ & 10 & 0.001 & Tnfsf11 & $10.44 \pm 0.47$ & $8.68 \pm 0.28$ & 3.4 & 0.029 \\
\hline Ccl5 & $5.80 \pm 0.05$ & $1.75 \pm 0.27$ & 16.6 & 0.008 & Xcl1 & $7.00 \pm 0.19$ & $5.29 \pm 0.23$ & 3.3 & 0.016 \\
\hline Cd40lg & $14.40 \pm 0.61$ & $8.19 \pm 0.35$ & 74 & 0.016 & Ccl12 & $7.01 \pm 0.25$ & $3.70 \pm 0.30$ & 9.9 & 0.015 \\
\hline Csf2 & $12.12 \pm 0.45$ & $9.31 \pm 0.17$ & 7 & 0.002 & $\mathrm{Ccl} 7$ & $6.68 \pm 0.33$ & $3.63 \pm 0.36$ & 8.3 & 0.027 \\
\hline Cxcl10 & $8.91 \pm 0.06$ & $4.99 \pm 0.31$ & 15.1 & 0.012 & Cxcl5 & $10.50 \pm 0.10$ & $5.42 \pm 0.46$ & 34 & 0.049 \\
\hline Cxcl13 & $7.80 \pm 0.73$ & $4.10 \pm 0.13$ & 13 & 0.001 & Gusb & $2.88 \pm 0.09$ & $2.27 \pm 0.15$ & 1.5 & 0.035 \\
\hline Cxcl16 & $5.19 \pm 0.15$ & $3.27 \pm 0.20$ & 3.8 & 0.008 & $\| 12 a$ & $12.98 \pm 0.35$ & $11.79 \pm 0.26$ & 2.3 & 0.045 \\
\hline
\end{tabular}


Citation: Cerny KL, Fleet MV, Slepenkin A, Peterson EM, Bridges PJ (2015) Differential Expression of mRNA Encoding Cytokines and Chemokines in the Reproductive Tract after Infection of Mice with Chlamydia trachomatis . Reprod Syst Sex Disord 4: 1000152. doi: 10.4172/2161-038X.1000152

Page 4 of 8

\begin{tabular}{|l|l|l|l|l|l|l|l|l|l|}
\hline Cxc19 & $8.26 \pm 0.21$ & $2.47 \pm 0.18$ & 55.3 & 0.001 & II18 & $6.87 \pm 0.06$ & $5.92 \pm 0.11$ & 1.9 & 0.003 \\
\hline Fasl & $10.13 \pm 0.21$ & $6.46 \pm 0.20$ & 12.8 & 0.002 & II1b & $8.29 \pm 0.52$ & $5.55 \pm 0.33$ & 6.7 & 0.023 \\
\hline Ifna2 & $11.25 \pm 0.08$ & $12.23 \pm 0.38$ & 0.5 & 0.041 & Osm & $10.42 \pm 0.13$ & $8.05 \pm 0.13$ & 5.2 & 0.001 \\
\hline Ifng & $11.30 \pm 0.08$ & $7.21 \pm 0.28$ & 17.1 & 0.006 & Tnfff10 & $5.96 \pm 0.13$ & $4.12 \pm 0.29$ & 3.6 & 0.02 \\
\hline II12b & $10.68 \pm 0.24$ & $8.07 \pm 0.26$ & 6.1 & 0.007 & & & & & \\
\hline
\end{tabular}

Table 2: Effect of treatment on the expression of mRNAs in the uterus at 28 days post-infection. The normalized average $\Delta \mathrm{C}+$ value was calculated using GAPDH as the house-keeping gene. Fold change values (infected over control) in gene expression are presented as average fold change ( $2^{-}$ $($ average $\mathrm{Ct})$ for differentially expressed mRNAs $(\mathrm{P}<0.05)$.

Of the 6 inflammatory mRNAs that increased within vaginal tissue after infection, 4 were also differentially affected by treatment in uterine samples. In oviducts collected at 28 days post-infection, the expression of mRNA encoding 2 inflammatory genes increased and 1 gene decreased. Of the 3 inflammatory genes affected by treatment within the oviduct, mRNA encoding 1 gene, chemokine (c-c motif) ligand 12 (Ccl12), was also increased in uterine samples.
Experiment 2: Expression of mRNA encoding inflammatory genes in vaginal, uterine and oviduct tissues at 35 days postinfection

In vaginal tissue collected 35 days after infection, the expression of mRNA encoding 8 inflammatory genes was increased and 8 decreased when compared to controls (Table 1). In uterine samples collected at 35 days after infection, the expression of mRNA encoding 32 inflammatory genes increased and 6 genes decreased compared to controls (Table 3).

\begin{tabular}{|c|c|c|c|c|c|c|c|c|c|}
\hline \multicolumn{10}{|c|}{35 day infected vs. control } \\
\hline Gene Symbol & $\begin{array}{l}\text { Control Avg. } \\
\Delta C+\text { SEM }\end{array}$ & $\begin{array}{l}\text { Infected Avg. } \\
\Delta C+\text { SEM }\end{array}$ & Fold change & $p$-Value & Gene symbol & $\begin{array}{l}\text { control Avg. } \\
\triangle C+\text { SEM }\end{array}$ & $\begin{array}{l}\text { Infected Avg. } \\
\Delta C+\text { SEM }\end{array}$ & Fold change & $p$-value \\
\hline Ccl1 & $13.26 \pm 0.25$ & $11.66 \pm 0.25$ & 3 & 0.016 & $\| 27$ & $12.87 \pm 0.30$ & $9.73 \pm 0.27$ & 8.8 & 0.012 \\
\hline Ccl17 & $9.41 \pm 0.15$ & $7.97 \pm 0.34$ & 2.7 & 0.041 & Lta & $10.67 \pm 0.19$ & $9.22 \pm 0.05$ & 2.7 & $<0.001$ \\
\hline $\mathrm{Ccl} 2$ & $6.72 \pm 0.14$ & $5.44 \pm 0.17$ & 2.4 & 0.007 & Ltb & $6.92 \pm 0.19$ & $4.28 \pm 0.09$ & 6.2 & $<0.001$ \\
\hline $\mathrm{Ccl} 22$ & $8.69 \pm 0.15$ & $7.22 \pm 0.15$ & 2.8 & 0.005 & Tgfb2 & $1.26 \pm 0.14$ & $3.70 \pm 1.24$ & 0.2 & 0.021 \\
\hline $\mathrm{Ccl} 24$ & $11.25 \pm 0.08$ & $13.93 \pm 0.94$ & 0.2 & 0.012 & Tnf & $9.73 \pm 0.09$ & $6.98 \pm 0.28$ & 6.7 & 0.013 \\
\hline $\mathrm{Ccl} 3$ & $10.83 \pm 0.31$ & $8.35 \pm 0.08$ & 5.6 & $<0.001$ & Tnfsf11 & $9.94 \pm 0.12$ & $9.06 \pm 0.14$ & 1.8 & 0.013 \\
\hline $\mathrm{Ccl} 4$ & $9.08 \pm 0.23$ & $6.26 \pm 0.04$ & 7 & $<0.001$ & Xcl1 & $7.12 \pm 0.19$ & $5.41 \pm 0.40$ & 3.3 & 0.05 \\
\hline Ccl5 & $5.47 \pm 0.21$ & $2.32 \pm 0.09$ & 8.9 & $<0.001$ & Adipoq & $11.58 \pm 1.29$ & $6.81 \pm 0.40$ & 27.2 & 0.034 \\
\hline Cd40lg & $13.94 \pm 0.93$ & $8.64 \pm 0.16$ & 39.4 & 0.001 & Cd70 & $11.19 \pm 0.19$ & $10.38 \pm 0.07$ & 1.7 & 0.008 \\
\hline Csf2 & $11.51 \pm 0.29$ & $8.78 \pm 0.16$ & 6.6 & 0.002 & Cntf & $7.99 \pm 0.08$ & $8.62 \pm 0.17$ & 0.6 & 0.023 \\
\hline Cxcl10 & $9.18 \pm 0.19$ & $5.08 \pm 0.27$ & 17.1 & 0.005 & Csf3 & $7.55 \pm 0.15$ & $6.56 \pm 0.18$ & 2 & 0.017 \\
\hline Cxcl13 & $8.83 \pm 0.27$ & $4.51 \pm 0.36$ & 20 & 0.017 & Cxcl1 & $11.41 \pm 0.43$ & $7.49 \pm 0.46$ & 15.1 & 0.029 \\
\hline Cxcl16 & $5.00 \pm 0.23$ & $3.14 \pm 0.13$ & 3.6 & 0.002 & Cxcl11 & $12.94 \pm 0.27$ & $6.26 \pm 0.34$ & 102.5 & 0.018 \\
\hline Cxcl9 & $8.06 \pm 0.22$ & $2.41 \pm 0.26$ & 50.3 & 0.006 & $\| 110$ & $11.18 \pm 0.41$ & $8.77 \pm 0.15$ & 5.3 & 0.003 \\
\hline Fasl & $10.25 \pm 0.04$ & $6.92 \pm 0.29$ & 10.1 & 0.013 & $\| 21$ & $15.24 \pm 0.15$ & $10.55 \pm 0.46$ & 25.8 & 0.047 \\
\hline Ifna2 & $10.87 \pm 0.31$ & $12.36 \pm 0.33$ & 0.4 & 0.037 & $\| 3$ & $15.11 \pm 0.11$ & $14.13 \pm 0.22$ & 2 & 0.026 \\
\hline Ifng & $10.76 \pm 0.16$ & $7.33 \pm 0.09$ & 10.8 & $<0.001$ & Thpo & $11.89 \pm 0.16$ & $13.27 \pm 0.36$ & 0.4 & 0.02 \\
\hline$\| 12 \mathrm{~b}$ & $10.31 \pm 0.23$ & $8.46 \pm 0.12$ & 3.6 & 0.002 & Tnfsf10 & $5.82 \pm 0.18$ & $3.80 \pm 0.19$ & 4 & 0.004 \\
\hline
\end{tabular}


Citation: Cerny KL, Fleet MV, Slepenkin A, Peterson EM, Bridges PJ (2015) Differential Expression of mRNA Encoding Cytokines and Chemokines in the Reproductive Tract after Infection of Mice with Chlamydia trachomatis . Reprod Syst Sex Disord 4: 1000152. doi: 10.4172/2161-038X.1000152

Page 5 of 8

\begin{tabular}{|l|l|l|l|l|l|l|l|l|l|}
\hline$\| 16$ & $7.75 \pm 0.11$ & $6.75 \pm 0.20$ & 2 & 0.02 & Vegfa & $4.23 \pm 0.13$ & $4.83 \pm 0.09$ & 0.7 & 0.023 \\
\hline
\end{tabular}

Table 3: Effect of treatment on the expression of mRNAs in the uterus at 35 days post-infection. The normalized average $\Delta \mathrm{C}+$ value was calculated using GAPDH as the house-keeping gene. Fold change values (infected over control) in gene expression are presented as average fold change ( $2-$ (average $\mathrm{Ct})$ for differentially expressed mRNAs $(\mathrm{P}<0.05)$.

Of the 16 inflammatory mRNAs affected by treatment in vaginal tissue, 7 were also differentially expressed in uterine samples and 3 in oviduct samples. In oviducts collected at 35 days post infection, the expression of mRNA encoding 13 inflammatory genes was increased and 1 gene decreased (Table 4 ).

\begin{tabular}{|c|c|c|c|c|}
\hline \multicolumn{5}{|c|}{28 Day infected vs. control } \\
\hline Gene Symbol & Control Avg. $\Delta \mathrm{C}+$ SEM & Infected Avg. $\Delta C+$ SEM & Fold change & $p$-value \\
\hline Ccl12 & $6.81 \pm 0.37$ & $4.39 \pm 0.51$ & 5.3 & 0.045 \\
\hline$\| 13$ & $10.45 \pm 0.21$ & $11.69 \pm 0.28$ & 0.4 & 0.029 \\
\hline $1123 a$ & $11.43 \pm 0.10$ & $10.96 \pm 0.08$ & 1.4 & 0.021 \\
\hline \multicolumn{5}{|c|}{35 Day infected vs. control } \\
\hline Bmp7 & $7.97 \pm 0.21$ & $6.99 \pm 0.12$ & 2 & 0.011 \\
\hline Ccl17 & $7.11 \pm 0.52$ & $6.19 \pm 0.32$ & 6.1 & 0.021 \\
\hline Cd40lg & $13.02 \pm 0.30$ & $10.40 \pm 0.36$ & 6.2 & 0.03 \\
\hline $\mathrm{Cx} 3 \mathrm{cl} 1$ & $5.16 \pm 0.21$ & $4.16 \pm 0.18$ & 2 & 0.025 \\
\hline Cxcl1 & $12.57 \pm 0.25$ & $9.99 \pm 0.24$ & 6 & 0.007 \\
\hline Fasl & $12.75 \pm 0.66$ & $8.79 \pm 0.34$ & 15.6 & 0.019 \\
\hline Gpi1 & $2.71 \pm 0.04$ & $1.56 \pm 0.26$ & 2.2 & 0.039 \\
\hline Hsp90ab1 & $0.53 \pm 0.18$ & $1.98 \pm 0.26$ & 2.7 & 0.027 \\
\hline$\| 12 b$ & $13.10 \pm 0.24$ & $10.47 \pm 0.17$ & 6.2 & 0.003 \\
\hline$\| 1 \mathrm{a}$ & $11.42 \pm 0.22$ & $9.65 \pm 0.23$ & 3.4 & 0.011 \\
\hline 119 & $7.16 \pm 0.21$ & $8.21 \pm 0.26$ & 0.5 & 0.044 \\
\hline Lif & $10.03 \pm 0.38$ & $8.77 \pm 0.08$ & 2.4 & 0.016 \\
\hline Mif & $1.55 \pm 0.09$ & $0.17 \pm 0.29$ & 2.6 & 0.044 \\
\hline Osm & $11.50 \pm 0.44$ & $9.93 \pm 0.33$ & 3 & 0.047 \\
\hline
\end{tabular}

Table 4: Effect of treatment on the expression of mRNAs in the oviduct at 28 and 35 days post-infection. The normalized average $\Delta C+$ value was calculated using GAPDH as the house-keeping gene. Fold change values (infected over control) in gene expression are presented as average fold change $\left(2^{-(\text {average } \mathrm{Ct})}\right)$ for differentially expressed mRNAs $(\mathrm{P}<0.05)$.

Of the 14 inflammatory mRNAs affected by treatment within the oviduct, 5 were also differentially expressed in uterine samples and 3 in vaginal tissue.

\section{Discussion}

The host response to infection with $C$. trachomatis includes the induction of pro inflammatory cytokines and chemokines which leads to innate and adaptive immune cell recruitment and activation [24]. Although the immune response is critical to the clearance of infection, the cellular immune response in particular can cause tissue damage that promotes fibrosis and can lead to infertility [16]. Considering that infection with $C$. trachomatis is often asymptomatic, the objective of these two experiments was to identify inflammatory mediators induced during the later phases of low-dose C. trachomatis genital infection in order to advance our understanding of disease progression and the immune response involved in potentially asymptomatic chronic inflammation.

It is well known that susceptibility to $C$. trachomatis infection is genetically controlled in mice. Both Tuffrey et al. [25-27] and Peterson et al. [19-21] have shown that human serovars of $C$. trachomatis can infect the genital tract of mice, specifically $\mathrm{C} 3 \mathrm{H} / \mathrm{HeJ}$ mice. Progesterone pretreatment is necessary, but this strain of mice remains 
culture positive for more than 4 weeks following infection [20]. In the current study, infected mice continued to have positive vaginal $C$. trachomatis cultures for the duration of the experiments with IFUs lower when the mice were killed compared to the first two weeks of infection.

In experiment 1 , mice were killed 28 days post-infection. In vaginal tissue, mRNA encoding several cytokines and chemokines was affected by infection with C. trachomatis. Among differentially-regulated genes in vaginal samples, the expression of mRNA encoding chemokine ( $\mathrm{c}-\mathrm{c}$ motif) ligand $4(\mathrm{Ccl} 4)$, also known as macrophage inflammatory protein-1 $\beta$ (MIP-1 $\beta$ ), a potent lymphocyte chemo attractant, was induced at 28 days of infection, with greater than a 6-fold increase compared to controls. C-C motif chemokines are a subgroup of chemokines with two adjacent cysteine residues near the amino terminus [28]. Yilma et al. [29] reported an increase in Ccl4 production in mouse macrophages during the early response to $\mathrm{C}$. trachomatis infection; therefore, our results suggest that this cytokine is actively involved in both the early response and late phases of infection. Interestingly, $\mathrm{Ccl} 4$ is highly related to macrophage inflammatory protein-1a $(\mathrm{Ccl} 3)$ and it is thought that these $\mathrm{C}-\mathrm{C}$ motif chemokines are secreted to recruit specific $\mathrm{T}$ cell subsets during the immune response [30,31]. In our study, expression of mRNA encoding Ccl3 in the vagina was also increased at 28 days post-infection.

Of all the differentially affected mRNAs in vaginal tissue, the largest fold-change in 28 day infected samples was seen in the induction of mRNA encoding CD40 ligand (Cd40lg). Cd40lg is mostly found on the surface of $\mathrm{CD} 4+\mathrm{T}$ cells and its interaction with $\mathrm{Cd} 40$ is required in the activation of humoral and cellular immune responses [32].

Within the uterus, treatment affected the expression of mRNA for five $\mathrm{C}$-X-C motif chemokines. C-X-C motif chemokines are a subgroup of chemokines that have amino terminus cysteine residues separated by one amino acid [28]. Most notable is the induction of mRNA encoding chemokine ( $\mathrm{c}-\mathrm{x}-\mathrm{c}$ motif) ligand 9 ( $\mathrm{Cxcl} 9)$. Previous studies have reported that $\mathrm{Cxcl} 9$ peaks during the early phases of infection in the upper genital tract and may be involved in Th1 responses [5], our results suggest that within the uterus, Cxcl9mediated inflammation remains ongoing even after the initial phase of infection. The expression of mRNA encoding several interleukins was also induced in the infected mouse uterus at 28 days post-infection, including Il1b, Il12a, Il12b, Il16, Il18, and Il27. Notably, Il12 is also reported to be involved in Th1 responses [33]. In our results, mRNA for Il12 subunit alpha (Il12a) and subunit beta (Il12b) was induced at 28 days after infection. Several tumor necrosis factor family members and interferons were also induced, supporting the hypothesis that inflammation remains active and ongoing within the uterus during the late, resolution phase of infection.

When compared to the response observed in vaginal and uterine tissues at 28 days, the oviduct had fewer mRNA differentially expressed after infection of mice with $C$. trachomatis.

The expression of mRNA encoding two genes was increased and one gene decreased. C. trachomatis-induced cell death within the oviduct is of concern due to long term sequelae, especially when considering that upon initial intracellular invasion of epithelial cells, $C$. trachomatis has the ability to prevent apoptosis of infected cells, therefore promoting infection $[8,13,14]$. Interestingly, the expression of mRNA encoding fas ligand (TNF superfamily, member 6; Fasl), a key mediator of apoptosis, was not affected by treatment at 28 days post infection within the oviduct.
In experiment 2, mice were killed 35 days post-infection. The level of mRNA encoding 4 interleukins (Il10, Il11, Il1rn, Illa) was increased and 1 interleukin (Il18) decreased in vaginal tissue collected at 35 days post-infection. Of these, Il18 is reported to interact with $\mathrm{Il} 12$ to stimulate interferon gamma (IFN- $\gamma$ ) production from NK cells during the early host response to infection [34]. Although studies have reported that IFN- $\gamma$ is crucial for immune cell responses to $C$. trachomatis [34-36], the expression of mRNA for Il12 did not differ at 35 days after infection and there was a decrease in levels of mRNA for I118. Furthermore, IFN- $\gamma$ had the greatest fold change of all differentially induced mRNA in the infected vaginal tissues, suggesting that IFN- $\gamma$ production is being stimulated by other immunoregulatory factors at this later stage of infection.

The increase in expression of mRNA encoding Il10 within vaginal samples collected at 35 days after infection was not expected. Interleukin-10 is considered an anti-inflammatory cytokine and a recent study using $C$. trachomatis infected HeLa cells demonstrated that exogenous Il10 treatment decreased several inflammatory cytokines including TNF [37,38].

Similar to vaginal tissues, uterine samples collected 35 days postinfection with $C$. trachomatis had increased expression of Il10 and TNF. Furthermore, an increase in adiponectin (Adipoq) was observed. Similar to Il10, Adipoq has anti-inflammatory properties including regulating cell defense and survival during stress conditions $[39,40]$. In addition, a dramatic increase in the expression of mRNA for Cxcl11 (102-fold change) was observed. Cxcl11 shares features with Cxcl9 and Cxcl10, including induction by interferons and expression on activated Th1 cells [41,42]. It is reported that the Th1 response is crucial for controlling $C$. trachomatis infection, our results that mRNA for these transcripts were induced within the infected uterus is therefore consistent with other studies.

Within the oviduct mRNA encoding 13 genes was increased and one gene decreased at 35 days after infection. The expression of mRNA encoding fasl increased at 35 days after infection with a 15-foldchange. In addition, changes in mRNA for other inflammatory mediators involved in tissue damage were detected, including Ill-a, which is released from lysed cells and acts by stimulating further cytokine release from neighboring cells [10]. Interestingly, levels of mRNA for Leukemia inhibitory factor (Lif) were increased in 35 day infected oviducts. Guney et al. [43] demonstrated that LIF expression is increased in the oviducts of woman with ectopic pregnancies compared to non-pregnant woman. Furthermore, Ji et al. [44] proposed that LIF facilitates implantation of the embryo in the oviduct when the stromal surface is exposed due to epithelial cell shedding caused by chronic inflammation. The results shown here warrant further investigation especially since $C$. trachomatis have the ability to not only disrupt infected epithelial cells, but also non-infected cells in proximity to the infection [8]. In oviductal epithelia, these changes in gene expression and disruption of cellular processes can increase the risk of chronic inflammation-induced pelvic inflammatory disease and infertility.

Overall, this study examined the coordinated and concurrent expression of mRNA encoding multiple cytokines in spatially distinct sections of the reproductive tract. We investigated the later stages of infection using a relatively low infectious dose in order to obtain a better understanding of the genetic mechanisms involved in chronic inflammation and cellular damage. Differences in the magnitude of response to infection in differing regions of the reproductive tract were expected, as were differences in the level of expression of specific 
Citation: Cerny KL, Fleet MV, Slepenkin A, Peterson EM, Bridges PJ (2015) Differential Expression of mRNA Encoding Cytokines and Chemokines in the Reproductive Tract after Infection of Mice with Chlamydia trachomatis . Reprod Syst Sex Disord 4: 1000152. doi: 10.4172/2161-038X.1000152

Page 7 of 8

mRNAs within a tissue over time [5], illustrating well the dynamic nature of the inflammatory response to infection and the need for inclusive analyses of inflammatory mediators.

Understanding the mechanisms involved in the inflammatory response at late stages of infection should aid in the development of treatment options that minimize chronic inflammation-induced pelvic inflammatory disease and infertility.

\section{Acknowledgments}

This work was supported by National Institutes of Health Grants K12 DA014040 (P.J.B.), P01 HD071875 (P.J.B.), R33 AI079775 (E.M.P.), the University of Kentucky, and Kentucky Agricultural Experiment Station. The information reported in this paper (publication no. 15-07-104) is part of a project of the Kentucky Agricultural Experiment Station and is published with approval of the Director. The content is solely the responsibility of the authors and does not necessarily represent the official views of the National Institute of Allergy and Infectious Diseases or the National Institutes of Health. The funders had no role in study design, data collection and analysis, decision to publish, or preparation of the manuscript.

\section{References}

1. CDC: Sexually transmitted disease surveillance (2009). Atlanta, GA: US Department of Health and Human Services, CDC(2010).

2. Gomes JP, Borrego MJ, Atik B, Santo I, Azevedo J, et al. (2006) Correlating Chlamydia trachomatis infectious load with urogenital ecological success and disease pathogenesis. Microbes Infect 8: 16-26.

3. Agrawal T, Vats V, Salhan S, Mittal A (2009) Determination of chlamydial load and immune parameters in asymptomatic, symptomatic and infertile women. FEMS Immunol Med Microbiol 55: 250-257.

4. Paavonen J, Lehtinen M (1996) Chlamydial pelvic inflammatory disease. Hum Reprod Update 2: 519-529.

5. Maxion HK, Kelly KA (2002) Chemokine expression patterns differ within anatomically distinct regions of the genital tract during Chlamydia trachomatis infection. Infect Immun 70: 1538-1546.

6. Soper DE (2010) Pelvic inflammatory disease. Obstetrics and gynecology 116: 419-428.

7. Miyairi I, Ramsey KH, Patton DL (2010) Duration of untreated chlamydial genital infection and factors associated with clearance: review of animal studies. Infectious Diseases 201, Suppl 2: 96-103.

8. Kessler M, Zielecki J, Thieck O, Mollenkopf HJ, Fotopoulou C (2012) Chlamydia trachomatis disturbs epithelial tissue homeostasis in fallopian tubes via paracrine Wnt signaling. American journal of pathology 180: 186-198.

9. Moulder JW (1991) Interaction of chlamydiae and host cells in vitro. Microbiol Rev 55: 143-190.

10. Rasmussen SJ, Eckmann L, Quayle AJ, Shen L, Zhang YX (1997) Secretion of proinflammatory cytokines by epithelial cells in response to Chlamydia infection suggests a central role for epithelial cells in chlamydial pathogenesis. Clinical Investigation 99: 77-87.

11. Zhong G, Fan P, Ji H, Dong F, Huang Y (2001) Identification of a chlamydial protease like activity factor responsible for the degradation of host transcription factors. J Exp Med 193: 935-942.

12. Zhong G, Fan T, Liu L (1999) Chlamydia inhibits interferon gammainducible major histocompatibility complex class II expression by degradation of upstream stimulatory factor 1.J Exp Med189: 1931-1938.

13. Igietseme JU, Omosun Y, Partin J, Goldstein J, He Q(2013) Prevention of Chlamydia-induced infertility by inhibition of local caspase activity. J Infect Dis 207: 1095-1104.

14. Zhong G (2011) Chlamydia trachomatis secretion of proteases for manipulating host signaling pathways. Front Microbiol 2: 14.
15. Belay T, Eko FO, Ananaba GA, Bowers S, Moore T(2002) Chemokine and chemokine receptor dynamics during genital chlamydial infection. Infect Immun 70: 844-850.

16. Brunham RC, Rey-Ladino J (2005) Immunology of Chlamydia infection: implications for a Chlamydia trachomatis vaccine. Nat Rev Immunol 5: 149-161.

17. Darville T, O'Neill JM, Andrews CW, Jr., Nagarajan UM, Stahl L(2003) Toll like receptor-2, but not Toll-like receptor-4, is essential for development of oviduct pathology in chlamydial genital tract infection. J Immunol 171: 6187-6197.

18. Byrne GI (2010) Chlamydia trachomatis strains and virulence: rethinking links to infection prevalence and disease severity. J Infect Dis 201 Suppl 2: 126-133.

19. Peterson EM, You JZ, Motin V, de la Maza LM (1999) Intranasal immunization with Chlamydia trachomatis, serovar E, protects from a subsequent vaginal challenge with the homologous serovar. Vaccine 17: 2901-2907.

20. Slepenkin A, Chu H, Elofsson M, Keyser P, Peterson EM (2011) Protection of mice from a Chlamydia trachomatis vaginal infection using a Salicylidene acylhydrazide, a potential microbicide. Infectious Diseases 204: 1313-1320.

21. Peterson EM, Cheng X, Motin VL, de la Maza LM (1997) Effect of immunoglobulin G isotype on the infectivity of Chlamydia trachomatis in a mouse model of intravaginal infection. Infect Immun 65: 2693-2699.

22. Bridges PJ, Jeoung M, Shim S, Park JY, Lee JE(2012) Hematopoetic prostaglandin D synthase: an ESR1-dependent oviductal epithelial cell synthase. Endocrinology 153: 1925-1935.

23. Livak KJ, Schmittgen TD (2001) Analysis of relative gene expression data using real time quantitative PCR and the 2(-Delta Delta C(T)) Method. Methods 25: 402-408.

24. Darville T, Hiltke TJ (2010) Pathogenesis of genital tract disease due to Chlamydia trachomatis.Infectious Diseases 201 Suppl 2: 114-125.

25. Tuffrey M, Alexander F, Woods C, Taylor-Robinson D (1992) Genetic susceptibility to chlamydial salpingitis and subsequent infertility in mice. J Reprod Fertil 95: 31-38.

26. Tuffrey M, Alexander F, Conlan W, Woods C, Ward M (1992) Heterotypic protection of mice against chlamydial salpingitis and colonization of the lower genital tract with a human serovar $\mathrm{F}$ isolate of Chlamydia trachomatis by prior immunization with recombinant serovar L1 major outer-membrane protein. J Gen Microbiol 138 Pt 8: 1707-1715.

27. Tuffrey M, Alexander F, Taylor-Robinson D (1990) Severity of salpingitis in mice after primary and repeated inoculation with a human strain of Chlamydia trachomatis. J Exp Pathol (Oxford) 71: 403-410.

28. Laing KJ, Secombes CJ (2004) Chemokines. Dev Comp Immunol 28: 443-460.

29. Yilma AN, Singh SR, Morici L, Dennis VA (2013) Flavonoid Naringenin: A Potential Immunomodulator for Chlamydia trachomatis Inflammation. Mediators Inflamm 2013: 102457.

30. Taub DD, Conlon K, Lloyd AR, Oppenheim JJ, Kelvin DJ (1993) Preferential migration of activated CD4+ and CD8+ T cells in response to MIP-1 alpha and MIP-1 beta. Science260: 355-358.

31. Schall TJ, Bacon K, Camp RD, Kaspari JW, Goeddel DV (1993) Human macrophage inflammatory protein alpha (MIP-1 alpha) and MIP-1 beta chemokines attract distinct populations of lymphocytes. J Exp Med 177: 1821-1826.

32. Teruel M, Simeon CP, Broen J, Vonk MC, Carreira P, et al. (2012) Analysis of the association between CD40 and CD40 ligand polymorphisms and systemic sclerosis. Arthritis Res Ther 14: 154.

33. Perry LL, Feilzer K, Caldwell HD (1997) Immunity to Chlamydia trachomatis is mediated by $\mathrm{T}$ helper 1 cells through IFN-gammadependent and -independent pathways. J Immunol 158: 3344-3352.

34. Hook CE, Matyszak MK, Gaston JS (2005) Infection of epithelial and dendritic cells by Chlamydia trachomatis results in IL-18 and IL-12 production, leading to interferon gamma production by human natural killer cells. FEMS immunology and medical microbiology 45: 113-120. 
Citation: Cerny KL, Fleet MV, Slepenkin A, Peterson EM, Bridges PJ (2015) Differential Expression of mRNA Encoding Cytokines and Chemokines in the Reproductive Tract after Infection of Mice with Chlamydia trachomatis . Reprod Syst Sex Disord 4: 1000152. doi: 10.4172/2161-038X.1000152

Page 8 of 8

35. Ito JI, Lyons JM (1999) Role of gamma interferon in controlling murine chlamydial genital tract infection. Infect Immun 67: 5518-5521.

36. Al-Zeer MA, Al-Younes HM, Lauster D, Abu Lubad M, Meyer TF (2013) Autophagy restricts Chlamydia trachomatis growth in human macrophages via IFNG-inducible guanylate binding proteins. Autophagy 9: 50-62.

37. Yilma AN, Singh SR, Fairley SJ, Taha MA, Dennis VA (2012) The antiinflammatory cytokine, interleukin-10, inhibits inflammatory mediators in human epithelial cells and mouse macrophages exposed to live and UV-inactivated Chlamydia trachomatis. Mediators of inflammation 2012: 520174 .

38. Sabat R, Grutz G, Warszawska K, Kirsch S, Witte E(2010) Biology of interleukin-10.Cytokine Growth Factor Rev 21:331-344.

39. Wu L, Xu B, Fan W, Zhu X, Wang G(2013) Adiponectin protects Leydig cells against proinflammatory cytokines by suppressing the nuclear factor-kappaB signaling pathway. The FEBS journal 280: 3920-3927.
40. Kobayashi H, Ouchi N, Kihara S, Walsh K, Kumada M (2004) Selective suppression of endothelial cell apoptosis by the high molecular weight form of adiponectin. Circ Res 94: 27-31.

41. Loetscher M, Gerber B, Loetscher P, Jones SA, Piali L (1996) Chemokine receptor specific for IP10 and mig: structure, function, and expression in activated T-lymphocytes. Experimental Medicine 184: 963-969.

42. Yang CH, Wei L, Pfeffer SR, Du Z, Murti A (2007) Identification of CXCL11 as a STAT3-dependent gene induced by IFN. Immunology 178: 986-992.

43. Guney M, Erdemoglu E, Oral B, Karahan N, Mungan T (2008) Leukemia inhibitory factor (LIF) is immunohistochemically localized in tubal ectopic pregnancy. Acta Histochemica 110: 319-323.

44. Ji YF, Chen LY, Xu KH, Yao JF, Shi YF (2009) Locally elevated leukemia inhibitory factor in the inflamed fallopian tube resembles that found in tubal pregnancy. Fertility and Sterility 91: 2308-2314. 